\section{Dr Jekyll and Mr Hyde: a tale of mystery, morality and medicine}

\author{
John Launer
}

How many characters can you name from fiction who have become bywords for wickedness? One pair of names will almost certainly come to mind: Dr Jekyll and My Hyde. Even if you have never read the book, or seen one of the many movies based on it, you will immediately recognise what these two names signify: how some people can change in an instant between two apparently quite different personalities - kind and thoughtful at one moment but then suddenly possessed by cold rage or becoming violent. The 'Strange case of Dr Jekyll and Mr Hyde' by Robert Louis Stevenson tells the tale of a respectable London physician who is mysteriously beholden to a repulsive and ruthless individual living nearby, called $\mathrm{Mr}$ Hyde. ${ }^{1}$ The doctor has written an extraordinary will in Hyde's favour, specifying that Hyde should be his heir if he should ever disappear. Jekyll allows Hyde the key to the back door of his premises, and free rein within, to the disgust of his own servants. Jekyll's lawyer Mr Utterson suspects that Hyde is blackmailing the doctor for some shameful acts in his past. Utterson doggedly tries to piece the mystery together, against Jekyll's express request not to pry.

The horrific truth only becomes evident after Jekyll's death. Jekyll has attempted to discover the chemical formula for separating his good nature from his evil impulses, but the experiment has gone horribly wrong. Each time he takes the drug, it turns him into the vicious $\mathrm{Mr}$ Hyde, but when he drinks the antidote, he only returns to his mundane self and not the saintly person he had hoped to become. Worse than that, he feels an increasing compulsion to take the potion that divests him of all his virtues, while the antidote lessens in its duration each time, leaving him helplessly trapped in the person of Hyde, and committing escalating acts of depravity and eventually murder. At the climax of the novel, when the supply of the antidote fails altogether, and when Utterson is on the very point of solving the mystery, Jekyll takes his own life.

Correspondence to Dr John Launer, Associate Editor, Postgraduate Medical Journal, London WC1H 9JP, UK; johnlauner@aol.com

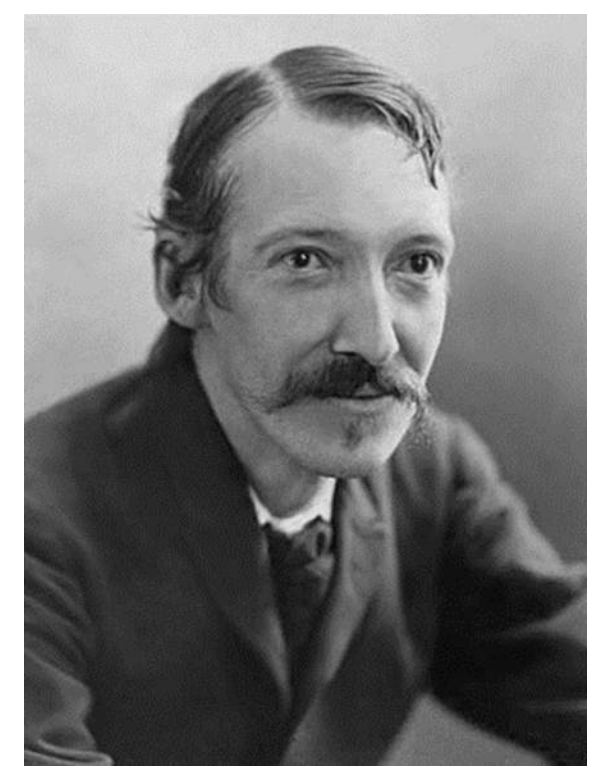

Figure 1 Robert Louis Stevenson

A mixture of horror story, science fiction, detective novel, psychological thriller and moral fable, 'Jekyll and Hyde' is a masterpiece of all these genres, and outclasses most later books written in any of them. Writing in the late nineteenth century, before explicit pornography was legal, Stevenson could do no more than hint at some of the vices that the doctor attempts to suppress, and his evil counterpart enacts, but in some ways the hints are even more suggestive than if everything was spelled out. The book acts as a parable about what it means to be a good doctor, or attempt vainly to become a perfect one, and it presents a deeply critical portrait of medicine, with its power and potential harms.

\section{COCAINE, ERGOT AND MORPHINE}

Stevenson (See figure 1) knew from personal experience how drugs could be both life-saving and terrifying as well as habit-forming. He suffered all his life from a respiratory disease that may have been tuberculosis. Around the time when he conceived Jekyll and Hyde, he was taking cocaine and ergot to control pulmonary bleeding, and morphine for pain. He experienced hallucinations, and the story in the novel came to him in an instant during a dream that may well have been fuelled by drugs. ${ }^{2}$ Although he was a Scot, Stevenson chose to locate his novel in central London. This allowed him to depict how the wealthy parts of the city, where society physicians like Jekyll practised, lay cheek by jowl with poor districts rife with poverty, alcoholism, prostitution, rent boys and criminality. He could also surround the action of his novel with evocative thick brown fog, to heighten the impression of moral fog, as Dickens had done. However, he almost certainly had a far more specific reason for choosing London: it connects the plot with one of the most famous figures in the history of British medicine.

The novel describes how Jekyll bought his house from 'the heirs of a celebrated surgeon.' It fronts a square of ancient and handsome houses. The household quarters lead on to a yard, and then to the deceased surgeon's dissecting theatre, now converted into Dr Jekyll's chemical laboratory. A flight of stairs goes up to the doctor's office, where he swallows his potions. The back of the house is windowless, with a 'blind forehead of discoloured wall.' It contains a dilapidated door, opening on to a by-street. It is through this doorway that $\mathrm{Mr}$ Hyde leaves and enters. It is only gradually that readers are led to realise that the door leads to Jekyll's residence, and to understand that the doctor's grand and welcoming front door connects with a back door resonant with sinister associations. As the novelist Ian Rankin has shown, ${ }^{34}$ Stevenson was almost certainly describing a real house, not a fictional one. The description fits the house in Leicester Square once occupied by John Hunter, the most celebrated British surgeon and anatomist of all time (see figure 2).

\section{JOHN HUNTER AND THE BODY SNATCHERS}

Hunter, another Scot, had been the most successful doctor in London in the eighteenth century, and surgeon to the King. In the days before anaesthetics, when surgery was still a barbaric and agonising procedure, Hunter made the specialty respectable and a subject of research. He created the vast anatomical collections that are now in the Hunterian museums at the Royal College of Surgeons of London, and in Glasgow. He depended for his work on a profuse and continual supply of cadavers, illicitly acquired. Although the front of his house was in a suitably fashionable 


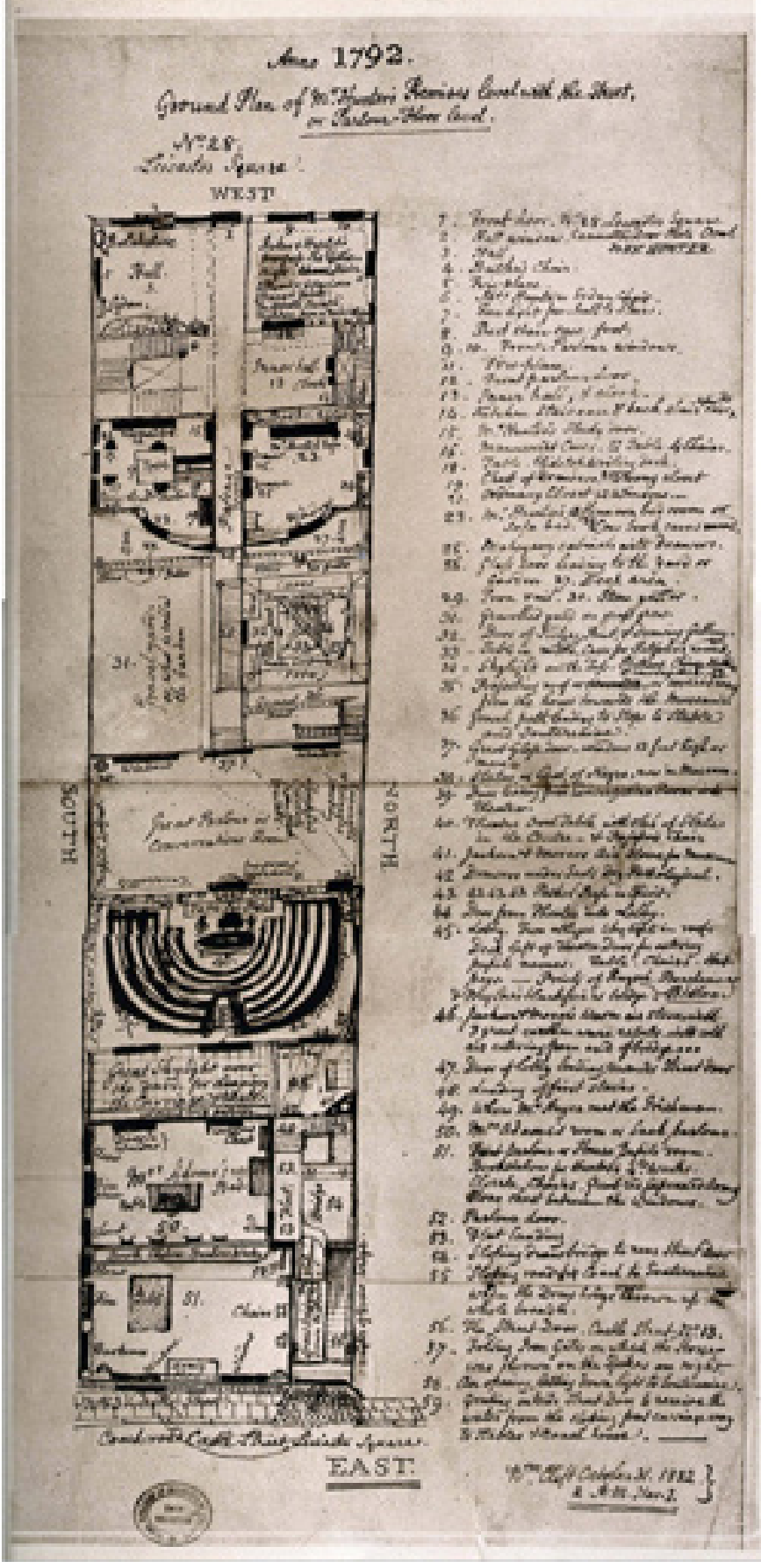

Figure 2 Plan of John Hunter's house in Leicester Square @ Wellcome Images

area, he linked it to another that backed onto the less reputable Castle Street (now Charing Cross Road). Between the two parts of the house he built a private museum for his specimens, and his dissection room. It was at the rear entrance that Hunter would have received the gruesome deliveries of the 'resurrection men' also known as 'body snatchers' or grave robbers. These deliveries notoriously included the body of the 'Irish Giant' Charles Byrne. Hunter had thwarted Byrne's wishes to be buried at sea in a lead coffin, by bribing the
Macfarlane who had managed to conceal his past as a ruthless anatomy demonstrator. In that role, Macfarlane had not only been a body-snatcher himself but, like the notorious Edinburgh murderers Burke and Hare, had on occasion killed for dissection material or to pre-empt blackmail.

It is impossible to draw any single moral from such a multi-layered novel, but there is no doubt that the most important part of the book is Jekyll's final written confession, read posthumously by his lawyer Mr Utterson. In it, the doctor describes his discovery of "the thorough and primitive duality of man" and his own tragically unsuccessful attempts to separate this duality. In the confession, Jekyll also anticipates the future direction of human understanding. "Others will follow, others will outstrip me on the same lines", he predicts, and hazards the guess that man will be ultimately known to be a collection of "multifarious, incongruous, and independent" personalities, all residing within a single individual.

It is an extraordinarily prescient idea, which fits with recent advances in our psychological and neurological understanding of human nature. As individuals, we are not divisible into identifiably good and bad parts as Dr Jekyll hoped, let alone capable of distilling ourselves into one or other aspect as he tried to do. Rather, we are each constituted from multiple identities - neither good, bad nor indifferent, but constituted from many conflicting desires, drives, needs and identities. Somehow, we have to find a way of living with all of these and accepting their contradictions, however uncomfortable this may make us. As Stevenson suggested, that goes for us as doctors too.

Funding The authors have not declared a specific grant for this research from any funding agency in the public, commercial or not-for-profit sectors.

Competing interests None declared.

Patient consent for publication Not required.

Provenance and peer review Not commissioned; internally peer reviewed.

(c) Author(s) (or their employer(s)) 2019. No commercial re-use. See rights and permissions. Published by BMJ.

As Rankin points out, Hunter's house was 'purpose-built for a surgeon's double life.' It was the kind of double life that Stevenson was fascinated by, and featured in a number of his stories and plays. Two years earlier, for example, he had published a ghost story called 'The Body Snatcher', that prefigured 'Jekyll and Hyde'. It centred around an elegant, charming and wealthy London physician called Wolfe 


\section{REFERENCES}

1 Stevenson RL. Strange case of Dr Jekyll and Mr Hyde, and other tales [1886]. Oxford: Oxford University Press, 2006.

2 Harman C. Robert Louis Stevenson: a biography. New York: Harper Collins, 2005.
3 lan Rankin investigates: Dr Jekyll and Mr Hyde. Available: https://www.bbc.co.uk/iplayer/episode/ b007qyzv/ian-rankin-investigates-dr-jekyll-and-mr-hyde [Accessed February 28 2019].

410 (more) fictional character addresses in London. 8. A square in SoHo. Available: https://exploring-london.com/ 2017/03/22/10-more-fictional-character-addressesin-london-8-a-square-in-soho/ [Accessed February 28 2019].

5 Stevenson RL. The body snatcher. In: Stevenson RL, ed. Strange case of Dr Jekyll and MR Hyde, and other tales [1886]. Oxford: Oxford University Press, 2006: 66-84. 